


\title{
LEITURA E ESCRITA DE PROFESSORES EM SUAS HISTÓRIAS DE VIDA E FORMAÇÃO
}

\author{
SONIA KRAMER \\ Professora da Pontifícia Universidade Católica do Rio de Janeiro
}

\begin{abstract}
Quem pretende se aproximar do próprio passado soterrado deve agir como um homem que escava. Antes de tudo, não deve temer voltar sempre ao mesmo fato, espalhá-lo como se espalha a terra, revolvê-lo comose revolve osolo.
\end{abstract}

Walter Benjamin

\begin{abstract}
RESUMO
Este artigo apresenta pesquisa sobre narrativa, experiências de leitura/escrita e memória de professores. Baseado na teoria crítica da cultura e da modernidade, em especial em Walter Benjamin, procura conhecer práticas de leitura e escrita de professores e compreender como foi construída - ao longo de suas trajetórias — sua relação com a escrita e de que forma tal relação influencia a prática escolar. Discute questões de natureza teórico-metodológica; apresenta as etapas da pesquisa, seus desafios e os principais achados, tratando do perío do exploratório (entrevistas com professores de pré-escola e las séries do 10 grau) e da investigação (entrevistas com professores que atuaram nas décadas de 20/30/40 e 50/60); e sintetiza o ensaio que vem sendo feito a partir de acervo de fotografias de situações de leitura e escrita captadas no cotidiano do Rio de Janeiro.

LEITURAEESCRITADEPROFESSORES — MEMÓRIA —POLITICASDELEITURAEESCRITA — FORMAÇÃO DEPROFESSORES
\end{abstract}

\begin{abstract}
READING AND WRITING EXPERIENCES IN TEACHERS'LIVES AND TRAJETORIES. This article presents a research about narrative, reading and writing experiences and teachers' biographies. Based on critical theory of culture and modernity, particularly on Walter Benjamin, the research intends to study reading and writing teachers' practices, to understand their relation with written language and to understand also in which way this relation influences pedagogic action. The article begins analysing theorethical and methodological questions; than it presents the phases performed by the research - exploratory period (when pre-school and elementary school teachers were interviewed), field study (when teachers that worked at the 20/30/40ies and the 50/60ies were interviewed), the main results; and, at the end, it summarizes the analyses that are being developed concerning reading and writing photographies in Rio de Janeiro daily life.
\end{abstract}

Este texto é parte de trabalho encomendado pelo GT de Alfabetização, Leitura e Escrita da Anped, apresentado na 20ª Reunião Anual, realizada em Caxambu, em setembro de 1998. A pesquisa recebeu apoio do CNPq e da Faperj. Participaram da equipe de pesquisa: Ana Beatriz Lopes de Lima, Aparecida Rodrigues da Silva, Clara Almeida e Silva (bolsistas de Iniciação Científica); Maria Cristina Carvalho, Rita de Cássia Frangella, Vânia Menezes, Eliane Fazolo Spalding (bolsistas de Aperfeiçoamento); Ilka Santos (mestranda) e Maria Isabel Leite (doutoranda). A revisão deste texto contou com a colaboração de Rita de Cássia Prazeres Frangella, a quem agradeço. 
Este texto tem como objetivo relatar a trajetória da pesquisa "Cultura, Modernidade e Linguagem". Situada nos campos da narrativa, leitura/escrita, memória e formação de professores, vem sendo desenvolvida com apoio do CNPq na modalidade de projeto integrado. Baseada na teoria crítica da cultura e da modernidade, particularmente em Walter Benjamin, a pesquisa procura conhecer experiências de leitura e escrita de professores, tecidas ao longo de suas histórias de vida e trabalho, abordando o processo de construção de conhecimento de professores, para compreender como foi construída sua relação com a escrita e de que forma esta relação influencia a prática escolar.

Em primeiro lugar, são discutidas questões de natureza teórico-metodológica; em seguida, são apresentadas as diferentes etapas da pesquisa, os desafios enfrentados e os principais achados. Trata-se do trabalho de campo (desde o período exploratório quando professores de pré-escola e primeiras séries do $1^{\circ}$ grau foram entrevistados), da pesquisa propriamente dita, centrada na análise de entrevistas feitas com antigos professores que atuaram nas décadas de 20/30/40 (em que a narrativa, a leitura e a escrita aparecem entrelaçadas com a própria tarefa de ser professor) e nos anos 50/60 (em que se destaca o significado da formação e o ato de tornar-se professor). A seguir, é mencionado o ensaio fotográfico feito a partir de acervo de situações de leitura e escrita no cotidiano do Rio de Janeiro, que vem sendo organizado nos dois últimos anos. Ao final, são apontadas perspectivas de continuidade e desafios agora enfrentados.

O projeto parte da compreensão da ação pedagógica como prática social e cultural, procurando entender o presente com o olhar iluminado pelo passado — ou pelas experiências passadas relatadas por professores - e tendo em vista especialmente a prática de profissionais envolvidos na formação. A pesquisa tem como propósitos: ampliar o conhecimento disponível sobre leitura/escrita; fornecer subsídios para políticas públicas, para políticas de leitura e de escrita e de formação de professores; sugerir alternativas para a leitura/escrita de professores, entendidas como parte de uma necessária política de distribuição dos bens culturais, uma das condições essenciais para a construção da democracia. Para alcançá-los, foram fundamentais a atuação integrada da equipe (graduandos, graduados e pós-graduandos) e a metodologia de trabalho adotada.

\section{LINGUAGEM, NARRATIVA, HISTÓRIA: REFERÊNCIAS TEÓRICO-METODOLÓGICAS}

Os pressupostos básicos da pesquisa residem na idéia de uma professora-Xerazade (Kramer, 1993). E o que isso significa? Recorrendo ao conto Mil e Uma Noites, encontramos Xerazade, capaz de enfrentar a ameaça imposta por quem tenta destruí-la: o rei. No conto, é Duniazade, sua irmã, que a ajuda a vencer a morte, ao aparecer a cada noite pedindo-lhe que conte mais uma história. $\bigcirc$ rei mantém-se assim interessado na narrativa, o que o impede de matar Xerazade, pois quer ouvir a continuidade da história. $\bigcirc$ rei simboliza nesse 
contexto o fracasso da escola; Duniazade representa as crianças que dão à professora-Xerazade a chance de manter-se viva: "o trunfo de Xerazade e a razão de seu triunfo é a narrativa" (Kramer, 1993. p. 193), "possibilidade de contar e de fazer história e não simplesmente esperar a morte" (p. 194). Ser professora-Xerazade significa superar a ameaça do fracasso e se tornar narradora. "Dizer que a professora é Xerazade é dizer que a prática de sala de aula é uma prática de narrativa" (p. 195).

Por outro lado, os pressupostos da pesquisa se enraízam na convicção de que para tornar seus alunos leitores e pessoas que gostem e queiram escrever, os próprios professores precisam estabelecer relações estreitas com a linguagem, experimentando a leitura e a escrita como prática social e cultural. Indagamos:

Como é possível a um professor ou a uma professora que não gosta de ler e de escrever, que não sente prazer em desvendar os múltiplos sentidos possíveis de um texto, trabalhar para que seus alunos entrem na corrente da linguagem, na leitura e na escrita? Inversamente, se o professor ou professora gosta de ler e de escrever, se é contador de casos e de histórias, o que (na sua trajetória de vida) favoreceu esse gostar, essa prática? Que relação professoras e professores têm com a linguagem no seu cotidiano? O que contam, lêem, escrevem? Como ocorreu essa relação com a escrita ao longo de suas histórias de vida construídas na coletividade? De que maneira esta experiência acumulada influencia a relação desses professores com seu trabalho? (Kramer, Souza, 1996. p. I8)

Essas questões continuam centrais também quando estudamos professores em processo de formação. Pensar a formação implica conhecer no presente aquilo que se anuncia para o futuro. Estivemos envolvidas em entrevistas com dois grupos de professores que atuaram na escola pública nas décadas de 20, 30, 40 (Menezes, 1996) e 50 e 60. Nesse percurso, orientou-nos a filosofia de Walter Benjamin, que, ao falar do conceito de história, entende que não é o passado que ilumina o presente ou o presente que ilumina o passado: presente e passado se conectam e se entrecruzam:

Benjamin fala do passado sempre como obra inacabada sobre a qual o sujeito deve trabalhar. Ser
sujeito da história é ter, portanto, a tarefa de tornar presente o tempo escondido sob as ruínas da
história universal... O dever do sujeito da história se liga, assim, aos sujeitos da história precedente que
foram vitimados pela barbárie — a da guerra, a da civilização que pasteurizou a cultura, a da opressão
de uma classe por outra. A história como continuidade é o que ele critica, procurando na descontinuidade
os momentos críticos, quando e onde podem ocorrer mudanças qualitativas. Nesse sentido, a
história não é vista como um "o que foi" apenas, mas como um "a se fazer", como uma ação ainda
possível! A noção de entrecruzamento do tempo se opõe, assim, à crença num passado imutável,
num presente imutável, num futuro também imutável. (Kramer, I993. p.50)

Vale ressaltar a importância que atribuímos à escrita. Compreender como se escreve a história, como se escreve o texto, relaciona-se à compreensão daquilo que se escreve em nós, daquilo que a nossa trajetória de aluno ou de professor inscreveu na prática cotidiana de cada qual. Reler essa prática, rever autobiograficamente a experiência passada, a situação 
presente e as perspectivas futuras significa ou implica reescrever essa história, dar-lhe outro sentido, ressignificá-la, mudar o futuro que se apresenta(va) com um inevitável tremor diante de uma folha em branco ou com uma incompreensível aversão a livros. A necessidade de formar professores que gostem de ler e não tenham medo ou vergonha de escrever tem sido o eixo da pesquisa.

Quanto ao referencial teórico-metodológico da pesquisa, analiso referenciais de Ciências Humanas/Sociais; de História, narrativa e rememoração; de leitura e escrita.

\section{Ciências Humanas/Sociais e pesquisa: questões no ponto de partida}

É possível explicar objetivamente o homem? Esta é certamente a grande questão das ciências humanas e sociais. Se nas ciências naturais o objeto de pesquisa era um produto acabado e passível de objetivação, nas ciências humanas e sociais, o objeto é o próprio homem e suas relações; um objeto em processo, inacabado, múltiplo, vivo, ideológico. Se nas ciências naturais a relação entre sujeito e objeto é de oposição da qual surge o conhecimento, nas ciências humanas não cabe cisão entre sujeito e objeto. Não há um sujeito que olha um objeto, mas um sujeito que reflete sobre si, sobre suas relações e constrói seu conhecimento. É, pois, um conhecimento produzido socialmente, situado na história e na cultura e não um conhecimento inteiramente objetivo.

A impossibilidade de explicar objetivamente o homem pelo modelo das ciências naturais lança às ciências humanas o desafio de compreender o homem na sua condição de ser ao mesmo tempo sujeito e objeto, produto e processo. $\bigcirc$ homem não é objeto e pensá-lo requer conjugar ao conhecimento científico as dimensões ética e estética. Longe de negar a cientificidade das ciências humanas, trata-se de construir outra forma científica de conhecimento, considerando que nas ciências humanas há um objeto que fala, pois "o homem só pode ser estudado como produtor de textos, como sujeito que tem voz, nunca como coisa ou objeto e, nesse sentido, o conhecimento só pode ter caráter dialógico" (Kramer, 1993. p. 106). Porém, sustentando uma tradição que opõe sujeito e objeto, as ciências naturais durante muito tempo, — e as humanas, ao copiarem seu modelo de investigação — , conceberam o sujeito como um ser desprendido de sua realidade social e histórica, instaurando o conceito de neutralidade científica. Sujeito e objeto foram condenados a produto; despindo-se de sua humanidade, o pesquisador tornou-se — em nome do rigor — prisioneiro da rigidez.

A teoria crítica da cultura e da modernidade e a sociologia crítica do conhecimento vêm redimensionar a relação sujeito-objeto: tanto o objeto quanto o sujeito das ciências humanas e sociais não são dados, mas construídos e compreendidos a partir de sua inserção na sociedade, na cultura, na linguagem, na história: só existe ciência que se pretende humana se ela é dialógica. Benjamin ( 1984 ) ajuda a aprofundar essa reflexão ao postular que é necessário construir outro referencial teórico-metodológico para as ciências humanas. Dirigindo sua crítica tanto à ciência quanto aos sistemas filosóficos, considera que ambos, na ânsia de 
dar conta da verdade, têm-na aniquilado, encarcerando-a, homogeneizando-a. Sua preocupação é a de não sacrificar a totalidade nem a singularidade deixando que o particular fale e revele as leis do todo; a verdade não se encontra nem no suposto universalismo totalizador, nem no particular, isolado e rechaçado pela ciência. Daí o valor do fragmento, da insignificância, do miúdo das histórias singulares. Nesta pesquisa, o caminho que pretendemos trilhar foi o da leitura do particular, trabalhando os fragmentos, os estilhaços, as ruínas (Kramer, 1993; Kramer, Souza, 1996), sem perder a dimensão do todo e buscando compreender a totalidade que neles se revela.

\section{História, narrativa e rememoração}

Ao pretender que a filosofia assumisse a forma poética, Benjamin falava das coisas miúdas do cotidiano, das ruínas, dos estilhaços, daquilo que parecia não ter importância, das sobras, das dobras, dos trapos, buscando em cada uma delas a sua dimensão de totalidade, refletindo, ampliando seu sentido, ressignificando as coisas mais simples da vida comum. Entendia, assim, que "o cronista que narra os acontecimentos sem distinguir entre os grandes e os pequenos, leva em conta a verdade de que nada do que um dia aconteceu pode ser considerado perdido para a história". (Benjamin, 1987a. p.223). Nesse sentido, uma das formas de humanização das ciências humanas passaria pelo desafio de resgatar a humanidade do homem, recuperando os elementos que the foram arrancados para que se pudesse convertê-lo em objeto. Resgatar a história das pessoas significa vê-las se reconstituírem em sujeitos e reconstituir sua cultura, seu tempo, sua história, reinventando a palavra. Tal resgate é crucial para a construção de um conceito humanizado de ciência: ouvir o que não pode ser expresso ou escutado, transformando as sobras em objeto de pesquisa, significa levar em conta o que estaria sendo supostamente tratado como lixo. A rememoração assume papel central, pois é também nas dobras do cotidiano que a história se realiza (Benjamin 1987a, 1987b).

Por outro lado, autores como Nóvoa (1992), Huberman (1992), Goodson (1992), Bosi (1993), Demartini et al. (1993), Sousa et al. (1996) dão contribuições importantes à compreensão dos professores como pessoas e profissionais. As narrativas, entrevistas autobiográficas, relatos de vida ou histórias de vida revelam a possibilidade de um novo campo em pesquisa educacional. Entrevistas que — como espaços de produção de narrativas — abremse, como textos que são, a múltiplas interpretações. Ora, ao entrevistar professores sobre suas práticas docentes, Goodson (1992) já mencionara como seus entrevistados falavam de suas histórias pessoais, o que o fez supor que os professores consideravam as questões da vida pessoal relevantes para a compreensão do cotidiano de sua prática docente. $\bigcirc$ autor alerta para a falta, nas pesquisas em educação, daquilo que para ele é o principal: a voz do professor. "O respeito pelo autobiográfico, pela vida, é apenas um dos aspectos duma relação que permite fazer ouvir a voz do professor" (p.7I). Desse modo, aprendemos que o autobiográfico é importante também quando os professores falam de seu trabalho. A história é, 
assim, compreendida como memória coletiva do passado, consciência crítica do presente e premissa operatória para o futuro (Ferraroti, 1982). É preciso, como diz Benjamin (1987a), não se contentar com um historicismo que apenas estabelece um nexo causal entre os vários momentos da história; nenhum fato é, por ser causa, um fato histórico. $\bigcirc$ historiador consciente disso "renuncia a desfiar entre os dedos os acontecimentos, como as contas de um rosário. Ele capta a configuração em que sua própria época entrou em contato com uma época anterior, perfeitamente determinada" (p. 232).

Lembrar é, então, assumir o tempo como medida humana, como história. A narrativa reinterpreta o passado e permite mudar um futuro que se mostrava inevitável. Como diz Benjamin (1 987a), passado, presente e futuro se conectam e se redimensionam em sempre novas constelações. Pela rememoração, na linguagem e na narrativa, resgata-se o poder de ser no presente, no passado e no futuro, possibilitando tecer o sentido da história, não mais como um encadeamento cronológico, mas como um processo de recriação do significado. Ao contar as histórias de leitura/escrita, o professor vai se lembrando da sua vida, dando a ela outros sentidos, antevendo mudanças na sua prática. Por outro lado, lembrar, nesse sentido, não é reviver, mas, refazer, reconstruir, repensar com imagens e idéias de hoje, as experiências do passado. A memória da pessoa liga-se, segundo Benjamin (1987a), à memória do grupo, aos elos e laços de coletividade, vincula-se à própria tradição. Para esse autor, precisamos estabelecer uma outra relação com a tradição e a cultura para não sermos aprisionados pela barbárie, o que acentua, mais uma vez, a necessidade da rememoração. $\bigcirc$ sujeito constitui a linguagem e é também constituído por ela (Vigotsky, 1984). Na linguagem, revivemos e refazemos a experiência vivida.

Leitura, escrita e pesquisa: algumas reflexões

sobre a formação do leitor

Ler é produzir significados. Escrever é marcar, mudar. Ser leitor é ser, então, produtor de significados. Mas numa sociedade elitista, configurada por seu caráter excludente, ainda marcada por significativo índice de analfabetismo, a idéia de crise de leitura parece preconceituosa? Ou, ao contrário, aceitar falar apenas em alfabetização significa excluir a maioria do direito de ser leitor e produtor de escrita?

A concepção de leitor abrange todas as categorias de material impresso, por diferentes formas de acesso, pois a maioria dos leitores se apropria de leituras diferenciais por meio de práticas diferenciais; a heterogeneidade marca o universo dos leitores e reflete-se na diversidade de práticas sociais de leitura. O leitor se constrói, pois, de forma complexa, nas práticas de leitura, com gestos, materiais impressos, desejo de ler, pelo contato físico e íntimo com o livro. Diversos setores sociais, servindo-se de teias de relações, são responsáveis pela formação da identidade social desses leitores. Vista dessa maneira, a entrada no mundo da leitura é fruto de relações simbólicas, sociais e econômicas; em outras palavras, a leitura refere-se à cultura popular, erudita e de massa; à família, escola, a outras instituições. 
Mas ler Dostoiévski tem o mesmo valor do que ler gibis? Como superar o aparente confronto entre a chamada boa leitura (Oswald, 1997) e a ênfase em práticas leitoras múltiplas (Dauster, 1996)? O conflito é aparente ou subjacente a ele e se coloca em diferentes perspectivas de democratização da escrita e de socialização do saber e da cultura? Essas questões serão enfrentadas na etapa atual da pesquisa.

E até que ponto alfabetizar implica formar leitores? A alfabetização pode se restringir ao domínio dos códigos, à capacitação para ler, sem formar o leitor. Já, a leitura extrapola a escola e a ampliação do acesso à escrita é crucial no processo de democratização. Um programa de leitura precisa levar em conta tudo que a leitura envolve. Afinal, é lendo que se aprende a ler; é escrevendo que se apreende o domínio da escrita, ou seja, que a escrita é internalizada e constitui a consciência, organiza a conduta, orienta as ações (Vigotsky, 1984). Formar leitores críticos é central para a consolidação da cidadania. Similarmente, a formação é direito de cidadãos. Mas a formação de leitores passa também pela ampliação do seu espectro cultural e de informações como o acesso a bibliotecas, exposições, feiras de livros, museus, teatros, cinemas, espetáculos musicais e de dança. Formular e implementar políticas públicas de investimento em leitura e escrita e de investimento em cultura deveria ser prioridade das políticas educacionais.

Vale ressaltar, entretanto, que embora a leitura não seja posse da escola, é papel da escola garantir a democratização da leitura e da produção da escrita. A leitura não pode ser reduzida a práticas extra ou intra-escolares, mas precisa ser encarada como importante no interior de um amplo projeto de política cultural que percebe a urgência de formar professores leitores e produtores de escrita. É uma aprendizagem não só da história, mas com a história: ouvindo, falando, contando, os professores repensam a história dando a ela um outro/novo significado, num processo contínuo e dinâmico de transformação. Tanto o estudo teórico quanto as atividades que temos desenvolvido na pesquisa — entrevistas e atas têm fornecido subsídios para compreender tal dimensão formadora. Do mesmo modo que para Benjamin, também para nós "pensar e escrever são fundamentalmente questões de resistência" (Sontag, 1986. p. I0I). Assim, a meta tem sido conhecer experiências de leitura e escrita de professores para propor alternativas de formação que se constituam em espaço de pensamento crítico, de escrita, de resistência.

\section{A PESQUISA EM CAMPO}

Neste item, são apresentados os projetos desenvolvidos ao longo de quatro anos: primeiro, o estudo realizado em caráter exploratório, em que foram entrevistados professores de pré-escola e primeiras séries da escola fundamental; em seguida, a pesquisa que levou em consideração as gerações de professores, bem como o exercício na rede pública, subdividindo a análise entre os professores que atuaram no início de século (anos 20, 30, 40) e aqueles que exerceram o magistério nas décadas de 50 e 60. 
Durante o período exploratório da pesquisa, ' entrevistando professores, ouvindo e transcrevendo relatos, buscamos compreender que relações professores e professoras estabeleceram com a escrita ao longo de suas trajetórias de vida e trabalho. E aprendemos a escutar palavras que falavam da importância de um pai, uma mãe, avó ou irmão na criação do gosto de ler, do papel secundário desempenhado pela escola; depoimentos que contavam da leitura forçada, do antigo (e perdido) gosto de ler, de muitas boas e más lembranças que a conversa de leitura e escrita neles suscitava, do dever de ler imposto pela escola em que um dia foram alunos. Ouvindo o que rememoravam, conhecíamos a história coletiva trançada pelos fios das histórias de cada indivíduo (Benjamin, 1987a): histórias que falavam de desprazer, imposição, obrigatoriedade, vontade de não ler.

Ora, mesmo não tendo chegado nesta etapa a grandes revelações, pois falar da mesmice da escola, da rotina da palavra e do pequeno espaço de criação não chega a ser novidade — ainda assim o assombro veio junto com o conhecimento, pela força das narrativas, pela aparente uniformidade das situações descritas, pela convergência dos problemas apresentados. A leitura na escola se fecha em leitura da escola, em que notas, provas de livros, fichas e apostilas com resumos das histórias ocupam o tempo e o espaço que, na concepção daqueles que preferem o gosto ao hábito, precisariam ser tempo e espaço de desfrutar o livro. Seria a aversão pelo textos literários unânime? Vários depoimentos apontaram que a escola teria um papel negativo na formação desse leitor: pela imposição de leituras, provas, datas, argüições, resumos, fichas, sínteses, a leitura seria reduzida à matéria, a conteúdo escolar. Ao mesmo tempo, os relatos sobre escrita vinham acompanhados de vergonha: ao relerem seus escritos, as próprias autoras rasgavam, ridicularizavam, queimavam ou jogavam os seus textos fora. A partir desses relatos, questionamos: a escola produz leitores ou estes se formam apesar da sua atuação inadequada? Mesmo sendo indiscutível o seu papel como instância divulgadora/promotora de cultura, parece que a escola — com a obrigatoriedade, a dissecação de textos — esteriliza as práticas de leitura e escrita.

Ao todo, entrevistamos 32 professoras de pré-escolar e de primeiro grau, de idades diferentes e que atuavam em escolas públicas e particulares (Kramer, Souza, 1996). Pelos depoimentos, percebemos que o gosto pela leitura é primordial na formação do leitor, gosto construído por experiências positivas, de práticas de leitura e escrita, de identificação de interesses, de liberdade (ou não) de escolher. Mas ao invés de dicotomizar obrigatoriedade/

I. O período exploratório refere-se ao projeto $\bigcirc$ que Narram, Lêem e Escrevem os Professores (Kramer, Souza, 1996). Para detalhes dessa etapa, ver Kramer (1995), em especial Ler, Escrever e Contar: os Professores e suas Experiências com Livros e Relatórios Parciais I, II, III da Pesquisa. 
livre escolha, entendemos como essencial haver práticas reais de leitura e escrita, como práticas sociais e culturais - convite à leitura e à escrita.

Além disso, as inquietações geradas ao longo da investigação disseminaram-se, ganhando também os domínios da sala de aula. Antes já era clara para mim a importância da pesquisa para o ensino e vice-versa: sempre analisei, com meus alunos, textos e artigos baseados em pesquisas e costumo partilhar com eles os estudos que realizo; com freqüência incentivo-os a participarem de seminários e busco conseguir bolsas de iniciação científica, aperfeiçoamento etc. Mas tratava-se aqui de algo diferente nascendo na minha própria prática diária de professora: germinava uma outra relação pesquisa-docência, calcada num estreito e dinâmico vínculo em que não só as situações cotidianas passaram a ser levadas para a pesquisa, não só as perguntas trazidas para o espaço pedagógico coletivo, mas também o próprio momento da aula tornou-se momento de pesquisa. Dessa forma, não resistindo, de um lado, à tentação de saber das histórias de alunos e alunas (eles e elas também professores ou futuros professores) e, de outro, considerando esse contar as histórias crucial no seu próprio processo de tornar-se professor (Kramer, 1993), suas trajetórias com livros passaram a ser um tema fundamental. $\bigcirc$ conjunto das conversas, entrevistas coletivas e inúmeras anotações pessoais realizadas neste percurso permitiu também aprender que mais do que não ler ou não gostar de ler, muitos dos professores haviam deixado um dia de ler.

Por outro lado, durante esses dois anos, certas questões começavam a nos inquietar: será que as práticas e a relação dos professores com a escrita se modificam nos diferentes momentos da história, ou seja, com as gerações? Como os professores que atuavam em distintos momentos e contextos relacionam-se com a escrita? De que modo as práticas de leitura e escrita foram (ou não) sendo marcadas pelas escolas que freqüentaram? Essas indagações originaram o projeto Leitura e Escrita de Professores em suas Histórias de Vida e Formação, etapa seguinte da pesquisa. A proposta não era confrontar a história relatada por eles com a história oficial mas sim, entrecruzar. Entrevistamos treze professores que se formaram e atuaram nos anos 20/30/40 e 50/60. O que dizem dessas épocas e de suas práticas tais professores é o que procuramos discutir nas duas seções a seguir. Uma caracterização breve dos professores entrevistados encontra-se em anexo.

Vida, trabalho e memória — relatos de antigos professores²

Qual o significado de ser professor nas décadas de 20, 30 e 40? Que práticas de leitura e escrita tinham os professores? "Eu fui tudo na vida, hoje eu não tenho nada, não sou nada..." (Professor Ciro, 76 anos, I/p. 159). ${ }^{3}$ E o que vamos achar nas memórias desses

2. Item produzido com base no texto de Brandão et al. in Kramer et al, 1997.

3. As falas dos professores encontram-se nos Relatórios Parciais I (Kramer et al., 1996) e II (Kramer et al. 1997), identificados no texto como I/p. e II/p. Todos os nomes são fictícios. 
antigos professores? Segundo Lispector (1986), "(...) é do buscar e não do achar que nasce o que eu não conhecia e que instantaneamente reconheço. E só quando falha a construção, é que obtenho o que ela não conseguiu" (p. |72).

Os professores entrevistados detêm um saber aprendido com o tempo vivido. Sem trabalho, fechados nas suas casas, resistem? Na rememoração, constróem-se como sujeitos históricos, com suas lembranças. Sobre isso, Benjamin diz:

\begin{abstract}
A língua tem indicado inequivocamente que a memória não é um instrumento para a exploração do passado; é, antes, o meio. É o meio onde se deu a vivência, assim como o solo é o meio no qual as antigas cidades estão soterradas. Quem pretende se aproximar do próprio passado soterrado deve agir como um homem que escava. Antes de tudo, não deve temer voltar sempre ao mesmo fato, espalhá-lo como se espalha a terra, revolvê-lo como se revolve o solo. (1987a. p.239)
\end{abstract}

Tentando alcançar passados soterrados nos deparamos com a surpresa de professores ao serem convidados a falar de sua vida e prática. Eles se surpreenderam ao se ouvir. Ao recordar suas experiências, ressignificam sua história (Bosi, 1993). A memória é o agente desencadeador desse processo de ressignificação que, lembra Benjamin, se desfaz por não assumir função utilitária para a modernidade. Os que vivem e rememoram a história sobrevivem ao tempo. "Eu estou me divertindo muito com vocês aqui, estou quebrando minha solidão, lembrando" (Adélia, 88 anos, I/p. 77).

As entrevistas transformaram-se em lições. Mais do que relatos de leitura e escrita eram histórias de vida sendo desveladas, refeitas e se, a princípio, os papéis pareciam delimitados, muitas vezes se invertiam: de entrevistadores passamos a entrevistados, pois eles nos faziam perguntas. Não éramos, portanto, só ouvintes.

Os entrevistados eram pessoas nascidas durante a República Velha que mais tarde foram trabalhar como professores da rede pública ou particular de algumas escolas do Rio de Janeiro. No início do século a modernidade se instalava: a década de 1920 vivia crise política e econômica com muitos movimentos populares no país, culminando na Revolução de 1930; a década de 30 começara com Vargas e a Aliança Liberal — o Brasil passava por uma crise econômica, com $80 \%$ de sua economia girando em torno da exportação. E a industrialização refletia-se no sistema educacional brasileiro. Em 1937, Vargas decretou o Estado Novo, período de ditadura e repressão. Lena, 72 anos, que participa de uma comissão formada por um grupo de professores aposentados no SEPE, ${ }^{4}$ conta: "Eu peguei duas ditaduras: 37 a 45 e depois 64 a 79." (I/p. 134). Tempos de silêncio. A primeira ditadura, porém, não repercutiu tanto sobre Lena, segundo conta: "não me atingiu muito diretamente, eu ainda não podia avaliar o que era ditadura, meu pai não se envolvia com política (...)" (I/p. 134).

4. O Sindicato Estadual dos Profissionais da Educação - SEPE — possui um grupo de aposentados que se reúne uma vez por semana para discutir questões da categoria. 
Em outubro de 1950, Vargas volta ao poder pela eleição direta, tendo recebido substancial votação. Sua campanha eleitoral baseava-se nos benefícios trabalhistas concedidos durante o Estado Novo e sua gestão daria continuidade à política populista. $\bigcirc$ professor Ciro cita com admiração a "história de Getúlio Vargas — o pai dos pobres". Nem todos eram ativistas políticos como Lena, nem todos dispensavam especial atenção ao cenário político, mas todos falam da escola, de ser professor, do magistério e da vocação. Adélia tem 88 anos, mora sozinha e toma conta de sua própria vida, da obra de sua casa, dos pagamentos bancários, dos ingressos do teatro que não deixa de assistir. Diz: "Eu me formei aos dezenove anos e trabalhei vinte cinco anos dos quais só tive cinco faltas. Eu fui jubilada como se dizia antigamente. Eu não tenho nenhuma queixa das crianças. Fui muito feliz com elas. Até hoje eu sonho que estou dando aula" (I/p. 72). Ela sonha ou ressignifica sua história relembrando momentos de aula?

As crianças não tinham apoio em casa porque eram filhos de analfabetos. Eu levava coisinhas para concretizar, materializar — feijão, milho, caixa de fósforo, palitinho — o ensino como era possível. Não conheço aritmética moderna e nem quero. Ensinei muita tabuada, ela é um período áureo da memória. Não há como exercitar melhor a memória do que com a tabuada. Eu não me limitava só a ensinar a tabuada, eu fazia, metodicamente, a adição, subtração, etc... Eu fazia no quadro negro e eles copiavam, depois eu passava os olhos... dizia: "Agora vamos estudar, procurar meter na cabeça". Tudo isso regrado para não ficar cansativo. Se não no mesmo dia, no dia seguinte. "Vamos fazer um concurso de contas?" Eles gostavam!! No meu concurso de contas quem tirasse o primeiro lugar ganhava um beijo. As crianças ficavam empolgadas. Eu passava aquele monte de continhas e depois levava para casa para corrigir, um por um. Se estava errado eu marcava, não deixava passar não. (Adélia, I/p. 73)

Como ela, também Vilma, 75 anos de idade, sempre na escola pública, relata: "Eu mesma era a explicadora dos meus próprios alunos e trazia os que mais precisavam para ensinar em casa para eles poderem acompanhar os outros, sem cobrar nada!" (Vilma, I/p. 92). Dizendo isso, Vilma quer fazer uma crítica à escola de hoje que, muitas vezes, sobrevive às custas de "explicadoras", moças de camadas populares que, no Rio de Janeiro, dão aulas e explicações para crianças que as escolas têm dificuldade de ensinar. Há, ainda, depoimentos que dão exemplos de práticas e métodos relativos à leitura e escrita. Dona Adélia mostra a importância de seguir com os alunos as fases da redação:

Eu contava histórias. As crianças fabulavam muito, criavam histórias, nas leituras a gente brincava com os sinais chamados letras. Eu ensinava a redigir. Encaminhava um assunto, desenvolvia aquele assunto e fazia ele morrer. Assim é que eu ensinava a redigir. Eu trabalhava muita redação com os alunos e depois fazia relatórios. Algumas escolas tinham uma porção de gravuras que eu mandava buscar para usar na redação. O que é que você está vendo? Eu fazia eles enumerarem, que é a primeira fase da redação. Depois contar o que viram, que é a segunda fase da redação. Depois façam uma frase, etc... Trabalhava as leituras oralmente. Depois eles escreviam. Trabalhava também individualmente. Com a $5^{\text {a }}$ série eu fazia leitura silenciosa. A leitura silenciosa é muito importante. Depois resumir o que leram. (Adélia, p.78) 
Por outro lado, Lara, que começou em 1918 como professora de escola particular, no Rio de Janeiro (a mesma em que estudou), fala de uma escola que a nossos olhos estigmatizadores não parece situada no início do século. Ela diz: "A ciência de ensinar são poucos alunos na sala, não pode ter mais do que a professora consegue dar conta" (repetiu isso várias vezes ao longo da tarde). "Eu dava aula conforme eu aprendi. Eram meninas de 810 anos. A professora sentava no meio e as meninas em volta, como um círculo" (ênfase minha):

\footnotetext{
Tomava lição de tudo. O negócio era assim, mandava as alunas estudarem e depois debatia com cada uma o que ela tinha estudado. Preparava cada papelzinho e tomava. Na aula de história discutia os assuntos todos, não decorava não...A leitura? Tinha leitura todo dia, era leitura do dia, elas preparavam e liam na sala. Cada uma lia e comentava. Ciências, para ensinar só com poucos alunos e não podia deixar o aluno por conta própria ou em qualquer outra matéria, porque senão todos vão acabar analfabetos. Éo que estáacontecendo hojeem dia. (Lara, I/p. 99)
}

Dona Lara enfatiza que naquela época não havia "decoreba"... havia leitura todo dia. Essa observação instigou a equipe. Indagamos: o que se perdeu entre essa escola chamada tradicional, mas que valorizava a aprendizagem "de cor" (de coração) e a nova que, na visão dessas professoras, só dá decoreba? Não será que, tal como as práticas múltiplas hoje existentes, também naquela época as práticas eram diferentes? E que papel a escola desempenha — ontem e hoje - em relação à leitura e à escrita? Dona Vilma reclama que hoje muita gente escreve errado: "(...) Antigamente o aluno copiava o ponto... chegava em casa e ainda passava a limpo. Hoje não, é tudo mimeografado, ninguém mais quase escreve. Há ditado ainda no primário? A gente tinha o ditado, tinha a cópia, havia redação que a gente levava pra casa pra fazer que era corrigida depois" (Vilma, I/p.92).

Nas entrevistas, deparamo-nos com a surpresa dos professores ao insistirmos na leitura e escrita; para elas e eles parecia não ser possível ensinar sem ler e escrever, como se a leitura e a escrita estivessem naturalizadas, sendo constituintes do próprio ato de ser professor, como se fossem parte da identidade do professor — ser professor era, de certo modo, relacionar-se fortemente com a leitura e a escrita. Hoje, ao contrário, a leitura e a escrita na escola estão descoladas de práticas culturais e sociais, reduzindo-se a atividades tais como provas, livros para ler com data marcada, questionários. As ações de ler e escrever possibilitam refletir sobre o mundo em que vivemos, criar e pensar sobre nossos escritos e leituras, transformando-nos em sujeitos. Nessa linha, Lena comenta:

A professora, tendo convicção daquilo que está fazendo e usando, de como está fazendo, dá certo...o que eu quero caracterizar é que a metodologia não é o mais importante, o mais importante é a competência da professora, quer dizer, como ela passa para as crianças. De uma forma sem ser autoritária. [...] De uma forma que a criança aceite como natural. Porque se não fosse assim, como foram alfabetizados nossos pais, nossos avós? [...] Então, acredito que, quando se faculta aos professores escolherem o seu método, é melhor. (Lena, I/p. I4I) 
E o que esses professores pensam sobre sua profissão? Como era? O que mudou? Ao fazer tais perguntas, ouvimos desabafos, desolação, ponta de tristeza na voz, relatos de situação de abandono, desrespeito. Longe da missão que sentiam cumprir, distantes da idéia de vocação e do respeito e reconhecimento da sociedade, com o tempo, ser professor se tornou desprestígio. Lena observa:

O professor que como eu começou em 1942 e se aposentou em 1977 presenciou grandes diferenças de tratamento e de condições [...] A sociedade tinha o maior respeito pelo professor. Trabalhava-se na favela e todos ajudavam. Não se tinha medo de traficantes, de tiroteio, de balas. Tinha-se a dificuldade de subir aquela ladeira, mas podia-se pegar carona. Hoje você pode pegar carona? Trabalhar numa favela é risco de vida. Os traficantes mandam recado para a escola não abrir e a escola não abre! A Secretaria é comunicada da ordem dos traficantes [...] Há um poder paralelo! [.... O respeito da sociedade pela profissão professor acabou! [...] em 46, quando a guerra terminou o professor ganhava igual a um capitão do exército. Há pouco tempo era igual a um cabo corneteiro... Nenhum professor resgatará sua cidadania ganhando tão mal... O resgate da nossa profissão passa pelo resgate da cidadania, de as pessoas compreenderem as funções do professor, do médico e respeitá-los. São profissionais que só fazem o bem e estão trabalhando pela comunidade. (Lena, I/p. 138)

Outros professores entrevistados fazem depoimentos semelhantes:

É muita pena... eu sinto tanta pena das professoras primárias hoje. As professoras de antigamente eram pessoas assim... de um nível muito bom, e agora não são... elas não têm o que dar, não é? E nem podem mesmo. Acho que hoje em dia talvez elas tenham mais dificuldades de acertar, porque hoje as professoras não têm gabarito nenhum para ser professoras primárias. As professoras de hoje não têm formação nenhuma. Eu não sei... eu não tenho ido lá [instituto de Educação], mas eu ouço falar que está muito ruim o nível delas. (Elizabeth, 7 I anos, II/p. 56)

Eu estive há pouco tempo no Instituto e me deu até vontade de chorar, no estado em que está! Tá horrível, táfeio. As meninas todas sentadas no corredor. Quando que isso acontecia no meu tempo?! [...] Batia a sineta e todo mundo tinha que entrar na sala e não se via uma pessoa no corredor. Isso é a falta de concurso. Hoje qualquer pessoa faz concurso. Aí eu vejo que o gabarito pra entrar é baixo [...] A vocaçãa éfundamental para ser professor. Hoje em dia não tem mais vocação, antigamente, tinha amor e respeito. Tia? Naquela época não se chamava de tia, era senhora, professora, dona, etc. (Vilma, 1/p. 89)

Se a escola pública já foi escrita com orgulho, hoje ela é marcada pelo descaso. Mas no tempo em que ensinavam, escola pública e qualidade andavam juntos. Naquela época, estudar em escola pública dava status. Nas memórias e experiências que relatam, leitura, escrita e cultura vêm junto com pai, mãe, irmão, avô, avó, amigo, primeira professora - a presença de uma pessoa que deixou marcas nas suas vidas, despertando paixão pelos livros, tornando-os leitores e contribuindo para sua visão do mundo: 
Mamãe e papai liam as expressões e eu gostava muito. Então, eu ficava sentada, ficava lendo... Eles liam e eu gravava! Depois ficava "lendo"...Parecia que eu estava lendo, tanta era a vontade que eu tinha de ler! Olhava as figuras e ficava lendo, ficava com aquela pose de ler... (Rosa, 80 anos, I/p. I I3)

Não tinha ninguém na minha família, o mais letrado era eu. Meus irmãos cursaram a escola, mas depois saíram. Foram trabalhar, mas não tinham capacidade nenhuma pra ensinar, nem leitura. (Ciro, I/p. 157)

... foi num meio de amor que eu fui criada! Meio de amor, mesmo! Então, quando o meu pai queria... Eu me lembro que ele me chamava, na minha casa: Você, uma menina bonita... Ele era poeta! Aí ele disse assim: Menina bonita, menina de trato, você é inteligente, você é prendada... Ele começava a elogiar primeiro, pra depois, então, dizer "não pode fazer isto". [...] Não tinha castigo! Minha mãe não dava. [...] Eu era muito enjoada pra comer, preguiçosa, pra comer. [...]Aí, a minha mãe me dava castigo. Fazia eu ficar três, quatro, cinco dias sem sobremesa. (Rosa, I/p. I l 0)

Embora estivéssemos interessadas em leitura e escrita, entrevistar pessoas de 72, 88 ou 95 anos, representou mais. Eles e elas compartilharam de nossas indagações, nos fizeram repensar a escola de ontem e de hoje, revelar mitos, contradições. Mais do que lembrada, a história foi ressignificada. Éclea Bosi diz que "a memória é a faculdade épica por excelência"; "a história deve reproduzir-se de geração a geração, gerar muitas outras, cujos fios se cruzem, prolongando o original, puxados por outros dedos" (1994, p.90). Nós vivemos isso e aprendemos que mais do que contar o passado elas queriam falar do presente e de seus planos para o futuro, planos de "mudar o Brasil".

Instituir-se professora — relatos dos anos $50,60^{5}$

Continuamos a pesquisa, ainda neste projeto que levou em conta a idade, com o mesmo objetivo de estudar a relação dos professores com a leitura/escrita. Mas ao analisar os relatos sobre os anos 50 e 60, constatamos que os docentes privilegiavam a identidade e a formação. Nesse contexto, o Instituto de Educação assumiu papel central nas narrativas. Falar de ser professor é falar do Instituto, voltar a lembranças, como diria Benjamin, escavadas na memória que descortinam sua formação. Nas diversas entrevistas realizadas ${ }^{6}$, o Instituto de Educação, a todo momento ressaltado, aparecia em imagens fortes. Elisabeth, uma das entrevistadas, diz que "naquela época... não era escola normal que se chamava... era Instituto de Educação" (II/p.58). Ter passado pelo Instituto ia além da formação profissional: mais que se formar professora, instituíam-se as pessoas na educação, no sentido de que as moças e rapazes eram impregnados de um ethos, imbuídos de uma forma de ensinar, de uma prática vivida como sendo a essencial de um professor.

5. Este item foi escrito com base no texto de Frangella et al. "Ser professora, instituir-se professora: a trajetória no Instituto de Educação". In: Kramer, 1997.

6. As falas das professoras que aparecem neste item encontram-se nos Relatórios Parciais I (Kramer et al., 1996) e II (Kramer et. al., 1997), sendo identificadas, no texto, como ( I/p.) ou (II/p.). 
Ora, as instituições de formação de professores, além de importantes quanto aos conhecimentos pedagógicos, são fundamentais na criação de normas de condutas comuns à profissão. Nóvoa ( 1995) considera que "mais do que formar professores (a título individual), as escolas normais produzem a profissão docente (em nível colectivo), contribuindo para a socialização dos seus membros para a génese de uma cultura profissional." (p. I 8). No Brasil, as primeiras escolas normais datam de meados do século XIX e foram se expandindo. Mas apesar de sua expansão, não garantiam, naquele momento, formação de qualidade nem se estruturavam com currículo comum (Freire, 1989). Por outro lado, a efervescência no panorama educacional na décadas de 20 e 30, com a Semana de Arte Moderna, a organização da Associação Brasileira de Educação — ABE — , o Manifesto dos Pioneiros e a Constituição de 1934, não valorizou o ensino normal, verdadeira contradição se levarmos em consideração os movimentos pela ampliação e implementação de um sistema de ensino para todos (Romanelli, 1978). O curso normal se tornaria alvo da política educacional em 1946, por meio de um dos decretos-leis - frutos da Constituição de 1937 -, que centralizavam as diretrizes do ensino: a Lei Orgânica do Ensino Normal. Até então, as escolas normais tinham sua administração e regulamentação a cargo dos estados da Federação, não constituindo, assim, um sistema estruturado. Aos poucos, de maneira fragmentada e desarticulada, foram criados diversos cursos — Escolas Normais Regionais, Escolas Normais e Institutos de Educação — , todos enfatizando no currículo matérias de cultura geral, mais que de formação profissional (Pimenta, 1992).

Instituto de Educação foi fundado no contexto de uma sociedade que vivia mudanças estruturais (de agrária à urbana), movimentação cultural, brasilidade, explosão de idéias. Os relatos das professoras mostram a dinâmica dessa sociedade, em que a opção pelo magistério permitia à mulher, em especial de classe média, exercer os papéis de mãe, mulher e profissional de modo respeitável, tornando a profissão de professora a melhor "escolha" no início do século. Assim, o Instituto de Educação surge como caminho "natural". Nesse sentido, Clara diz:

Eu acho que eu nasci mesmo para ser professora, eu queria era ser jornalista, mas na minha época era mal falado ser jornalista e não tinha escola de jornalismo, então você tinha que ir tirar escola jornalismo sendo foca de jornal na coluna social, aí era o meu noivo, um cara do exército e ia morar em Recife, eu ia ficar sem ele e ele sem mim... oh, paixonite... Minha mãe, tradicional, disse: "Não faz jornalismo". O meu pai me estimulou: "Faz jornalismo sim, minha filha". Mas falou mais alto a voz do coração, porque eu ia casare paraficar bem com o meu marido, fui ser professoramesmo. (II/p. I02)

Mas não, não era, assim, um desejo meu de ser professora. Realmente eu não me lembro nunca na minha vida de ter dito assim: "Ah, eu quero ser professora..." aquilo foi uma coisa... assim como se fosse já... estava escrito,... tipo assim: "Saiu da escola primária, faz admissão, pra fazer o concurso para o Instituto... (Marília, II/p. I06)

Não havia opção. Eu queria era ser bailarina. Bailarina realmente não estava nos planos de ninguém. [...] Quando eu escolhi a carreira (professora) não tinha muito o que escolher. "Não minha filha, você 
só pode ser professora, é a única carreira, eu nunca me esqueço (o que o pai lhe disse), compatível com a dignidade da mulher. (Luzia, II/p.88)

Nos seus depoimentos, quase todas mencionam o rigoroso processo de seleção para a entrada no Instituto:

[...] porque quando eu fui pro Instituto, eu fui pro primário fazendo concurso, não passei e aí, no $2^{\circ}$ ano, fiz o curso de admissão, todas faziam. Fazíamos primeiro o teste de Inteligência, se passasse fazia Matemática, se passasse fazia português e assim ia. Tinha provas orais. Quer dizer, era uma coisa bem puxada! A rua Mariz e Barros ficava cheia, do trânsito ficava quase parado, igual vestibular. Ficava assim pra gente entrar no Instituto. (Vilma) ${ }^{7}$

A prova era exame mesmo [...] a prova oral não era em sala, era no ginásio e quem quisesse assistir podia. Eram três examinadores [...] aquilo era normal naquela época. (Estela) ${ }^{8}$

Numa sociedade urbano-industrial, de demanda crescente por educação, a escola era símbolo de classe e forma de ascensão social (Romanelli, 1978). Como comenta Estela "a escola em si era respeitada. Era o centro da comunidade.... era o referencial". Foi nesse contexto e com suas contradições que a escola normal se estruturou. A industrialização aumentava a demanda por educação e provocava expansão do sistema escolar. Por outro lado, até a Lei de Diretrizes e Bases de 1961, o ensino secundário era dual: dos cursos profissionais, só a escola normal dava acesso ao ensino superior. Entrar no Instituto era afirmar uma posição de classe. Ser normalista extrapolava a condição de estudante; indicava valor social, presente na ênfase dada ao rigor do processo seletivo para o ingresso no Instituto. Como diz Vilma: "Era garantido! Quer dizer, ser normalista era uma honra. A começar pelo uniforme, que era rigoroso."9 Outras destacam também:

[...] tinha um certo orgulho... um certo orgulho em usar o uniforme, sempre bem... (Luzia) ${ }^{10}$

[...] fui fazer um ano de Guanabara pra me preparar para o Instituto. Entrei para o Instituto em 1950. Aí, é que foi o tempo maravilhoso da minha vida.(Clara, II/p.97)

[...] e a gente amava aquela escola como não se ama mais as escolas. Eu tenho uma pena quando eu passo ali e vejo o prédio daquele jeito. Na minha cabeça, nos meus retratos antigos, ele está intacto. Então, não faz muito mal porque eu vejo ele da forma que era. (Clara, II/p.97)

[... o Instituto era um todo, as turmas de primário tinham aula no térreo e o normal e o ginásio era no andar de cima. Em todas as salas, tinha, no fundo, essas cadeiras tipo de auditório, porque elas

7. Esta fala não consta dos Relatórios. Entrevista transcrita de fita gravada do arquivo da pesquisa (fita $\mathrm{VI}$ ).

8. Idem (fita 2A).

9. Idem (fita $\vee \mathrm{I})$.

10. Idem (fita 6A) 
(normalistas) assistiam às aulas dos professores. Então, as professoras já davam aula de acordo com o certo, para a professoranda aprender. Todas as aulas eram aulas mesmo, tinham técnicas perfeitas para elas aprenderem certo. "I

O Instituto de Educação fornecia o modelo de educação da época. Como explica Estela, "o grupo de professores lá era maravilhoso, muito bom. Tinha que ser, para servir de modelo para as outras escolas" (II/p.73). Esse modelo era o caminho a ser percorrido pelas professoras que começavam sua vida profissional pautando suas práticas nas práticas da instituição em que se formaram. Nos modos de ensinar e planos de ensino, residiam os conteúdos que deveriam ser aprendidos pelos alunos em condições e técnicas elaboradas para o bom êxito na aprendizagem. "O Instituto era todo programado com os alunos justamente para interessar os alunos, porque interesse é tudo" (Valda, II/p.89). Como diz Cavaco, "o professor jovem pode ser levado a reactualizar experiências vividas como aluno e elaborar esquemas de actuação que rotinizam e que se filiam a modelos tradicionais" ( 1995. p. | 64). E o Instituto assumia essa tarefa de prover os professores de modelos de ensino e de construir uma concepção do aluno ideal. Porém, ao entrar em sala de aula como professora, aparecia o confronto com outros pontos de vista e a contradição entre a realidade suposta na formação e a realidade encontrada:

[... ] quando eu comecei a trabalhar, eu comecei a trabalhar em Realengo, foi uma experiência boa. Porque é diferente trabalhar com um aluno do Instituto de Educação e o aluno de Realengo, da Escola Coronel Corsinto do Amarantes, crianças que iam para a escola de tamanquinho. [...] quase que eu desisto de ser professora nos meus primeiros anos de trabalho porque a realidade é muito dura, é diferente. Mas aí, a minha mãe me deu muita força: "Ah, quer dizer que porque agora viu dificuldades vai desistir? Você quer tudo flores? Aluno interessado, aluno bonzinho é ótimo. Eu quero ver você lidar com esses meninos que têm problemas!" Quer dizer, ela me espicaçou e aí eu consegui enfrentar a barra. (Luzia, II/p.87)

Me lembro muito da minha vida na escola normal como uma passagem assim muito bonita. Naquela época não era escola normal que se chamava... era Instituto de Educação. Era um prédio lindíssimo, que eu fui lá há pouco tempo e fiquei com tanta pena. Tá todo caindo, tá assim mal tratado [...] É uma preciosidade, era lindíssimo, um pátio interno, as salas de aula eram uma beleza. Eu peguei uma época muito boa. Villa Lobos, Malba Tahan, são pessoas que ficaram marcadas. (Elizabeth, II/p.57)

Mas os relatos mostram ainda a ênfase dada aos conteúdos:

[...] nosso curso não era igual ao de vocês... tínhamos umas dezoito disciplinas. (Valda, II/p.86)

Tinha as didáticas, metodologias eram separadas. Porque, hoje em dia, acho que é tudo globalizado, mas, antigamente erra tudo separado, além de Português, de Matemática. A gente estudavaAnatomia, Física, Química, Biologia, tudo. (Marilia, II/p. 107)

11. Idem (fita 2A). 
[...] o Normal não era só para ensinar; tinha as partes pedagógicas, tinha as didáticas, mas tinha História Natural, História das Américas, além de História Geral que nós tínhamos dado até a quarta série. Tinha Filosofia, tinha Puericultura; Higiene e Puericultura no curso Normal, Biologia, era um currículo muito bom, nós estudávamos Latim, Português, Inglês, Francês. (Estela, II/p.72)

O modelo pedagógico do Instituto de Educação, com professores catedráticos, tinha, na instrução, um dos alicerces de uma formação profissional consistente. Ler e escrever naquele momento fundamentais — eram práticas efetivas na formação. As professoras contam que ingressavam cedo no mundo da leitura/escrita e destacam a influência da família e da escola e seus professores (muitos escritores) na mediação de seu envolvimento com a leitura e escrita:

Bom, olha, meu pai sempre valorizou muito a questão da leitura, [...] a gente já tinha muita coisa em casa, em relação à leitura e o meu pai também já lia muito e tudo isso [...] papai era comerciante e minha mãe era de casa, não trabalhava fora, e... então a gente não tinha muito livro. [...] Olha, eu me lembro de um tio meu, irmão da mamãe, levou esse tal de primeiro livro [...] (Tereza, II/p. I I 7)

Eu li muito Jorge Amado. Meu pai comprava. Eu li muita poesia. Eu li Olavo Bilac. Em casa, tinha muito livro de poesia. (Clara, II/p. I O I)

É, eu tive influência de Malba Tahan. Fui aluna dele na $2^{\circ}$ série ginasial, de Matemática, é claro, mas ele era um professor que aliava a Matemática à Literatura. Ele passava os exercícios e quando chegava o número cem, chamava um escritor. Na minha turma foi o poeta Bastos Tigre. Nós fizemos festa para ele. E para quem tirava boas notas, Malba Tahan presenteava com livros dele ou de outros escritores. Eu tive muita influência dele. (Lena, I/p. I45) 12

Instituto de Educação preocupava-se com a leitura e a escrita que eram (e pelo que indicam os relatos ainda continuam sendo) também praticadas fora da escola: "Olha, eu escrevi carta de amor pro meu marido... No instituto, muitas aulas eu não assistia, ficava escrevendo cartas para ele. (...) Escrevi peça de teatro no Instituto, a peça se chamava assim 'Quem dera que fosse um bilhete premiado'... e aí vai" (Clara, II/p. I02). "No Instituto eu lia sim, lia jornal. Só não lia como leio hoje" (Vilma). ${ }^{13}$

Essas professoras formadas, naquela época, no Instituto parecem ter apego à escrita. Muitos foram os tipos de escrita citados nos relatos — para expressar sentimentos, sistematizar, planejar, refletir teoricamente e pensar o próprio mundo:

[...] eu já fiz umas poesias malucas...engraçado, eu gosto de escrever... de vez em quando me vem assim umas idéias e eu escrevo [...] Eu escrevo para os outros, eu tenho uma idéia, eu escrevo [...] (Marília, II/p. I I3)

12. Muitos depoimentos destacam a importância de terem tido escritores como professores.

13. Esta fala não está nos relatórios. Entrevista transcrita de fita gravada do arquivo da pesquisa (fita VI). 
Nessa fase que eu estive na secretaria, escrevia muito [...] pra professor, eu escrevia para professor não para a Academia, não era linguagem complicada, não rebuscada, que as pessoas reclamavam muito; eu lido muito com professores. Então.. elas reclamam muito. Elas dizem: "vocês escrevem que a gente não entende". Elas dizem muito isso. (Tereza, II/p. I 20)

Faço muitas cartas. Escrevo cartas, por exemplo, para as minhas amigas, pessoas que estão longe. (Elisabeth, II/p.66)

Quando falam da opção pelo magistério, do ingresso no Instituto ou de sua relação com a leitura/escrita, trazem a história de uma geração de mulheres, num momento em que ser professor caracterizava status social. Além disso, sinalizam a importância do Instituto no seu processo de formação e na construção da sua identidade. Instituindo-os de educação, constituindo-os como professores, o Instituto representava formação de qualidade, a todo momento ressaltada nos relatos. As entrevistadas, pelas suas histórias, falam da influência do Instituto no seu modo de ser professor, das lembranças de mestres e, com saudades, contam de seus anos lá vividos, os rastros e as marcas até hoje presentes em suas vidas.

\section{A FOTOGRAFIA COMO DESVIO METODOLÓGICO ${ }^{14}$}

Ao longo das entrevistas, percebemos que o processo de lembrança expressa em palavras e imagens o dito, o não-dito, o visível e invisível das histórias contadas. Ao entrevistar professoras do início e de meados do século, foi importante estudar a conjuntura política e econômica da época e também o contexto cultural que se exprime nas imagens, música, filmes, moda, obras de arte, livros. Com essa intenção, pedimos às professoras que trouxessem objetos e fotografias da infância e situações marcantes de sua vida pessoal e profissional. No momento das entrevistas, esses elementos concretos e visuais eram tratados como "imagem da memória". Mais do que ilustração, as fotografias foram processo deflagrador, ampliando a possibilidade de resgate da história de vida desses professores e de sua relação com a leitura e a escrita a partir da história contada pelas imagens. Assim, a fotografia não é trazida para a pesquisa como documento, prova do acontecido, mas como objeto da cultura, intermediado, de início pelo equipamento (aparato técnico de registro e revelação), pelo fotógrafo (sujeito vivo, subjetivo) e, no momento em que é revelada, pela interferência do sujeito contemplador. Cada fotografia está impregnada da realidade à mostra (e todas suas influências ideológicas), da possibilidade técnica (que muda a cada vez que é reproduzida, ampliada, copiada, reduzida) e do entrelaçamento das subjetividades do fotógrafo e dos contempladores, independentemente de seus tempos cronológicos ou espaços geográficos. Para Dubois "qualquer foto só nos mostra por princípio o passado, seja este mais próximo ou distante" (apud Lopes, 1996. p.74). Esse passado, lido aos olhos do presente, já não é o mesmo passado, mas sua leitura ressignificada.

14. Item elaborado com base no texto de Leite et al. 
Por outro lado, a partir do estudo da fotografia, começamos a registrar momentos nas ruas e em várias outras situações do cotidiano do Rio de Janeiro, buscando tanto nas imagens do passado, quanto nas situações do presente, material que possibilite refletir e discutir as prática de ler e de escrever. Dialogando com as linguagens e abordando ângulos diversos de um mesmo objeto de pesquisa, tem sido possível enriquecer as discussões sobre leitura/escrita e consolidar um outro campo de estudo: a fotografia como desvio metodológico. A foto passa a representar uma possibilidade de compreensão de tempo não linear (Benjamin, 1987a), que traz implícito em sua imagem explícita, o passado e o presente. É um constante convite à releitura, a uma forma diversa de ordenar o texto imagético. Ela pode ser olhada muitas vezes, em diferentes ordens e momentos, pode suscitar outras interpretações: será sempre uma foto outra ali presentificada. Uma foto que se transforma cada vez que é contemplada, que revive a cada olhar. É "uma narrativa interrompida, imobilizada num quadro único" (Leite, 1993. p.28).

Na relação da fotografia com a memória, a narrativa e a leitura/escrita, as imagens antes fixadas pelo acervo fotográfico dialogam com o acervo imagético pesquisador. Cada história, cada fragmento, cada foto, cada olhar, constitui-se no movimento de refotografar as imagens já fotografadas pela lente. Resgatar a memória e recontar a história é ressignificar o olhar... Ao longo da pesquisa, as entrevistas e o estudo provocam as indagações: as pessoas lêem e escrevem? O que se lê e se escreve? Estão as práticas de leitura e escrita restritas aos espaços de trabalho ou à escola? Existem espaços específicos para se ler e escrever? Há leitura e escrita por prazer? O que determina hoje o tempo de ler e escrever? Pode-se falar de leitura e escrita em tempos de espera? Como fazer da escola também um espaço de práticas de leitura e escrita? Será a leitura moderna ainda uma leitura solitária? Será oportuno opor ainda hoje leitura intensiva e leitura extensiva? Há espaço para leitores e produtores de escrita nos bairros em que se situam as escolas estudadas? Qual o contexto cultural destas escolas? Que relação temos hoje com a língua escrita e, particularmente, com o livro? Como cada um de nós - passantes, trabalhadores, viajantes, moradores, professores, pessoas em momentos de lazer ou de trabalho — relaciona-se com a leitura e a escrita?

Buscamos, no cotidiano, imagens que façam dialogar com essas questões. Contamos hoje com um acervo de 170 slides de leitura e escrita no Rio de Janeiro e com o ensaio fotográfico (Re)tratos da História de Professores: a Fotografia como Desvio Metodológico (Leite et al., 1997), como os primeiros passos na elaboração de um material experimental que tem o objetivo de provocar, junto a professores e futuros professores, a discussão e reflexão sobre suas experiências atuais com a leitura e a escrita.

\section{AINDA UMA VEZ - COMO ESTAMOS CONTINUANDO}

Além de discutir questões teóricas, organizar os resultados do trabalho de campo e apontar para políticas de leitura/escrita, temos aprofundado a reflexão sobre a própria prática 
da pesquisa, sistematizando as contribuições que pode trazer para a formação. Aqui se coloca o que temos denominado de dimensão formadora das entrevistas e dimensão formadora da escrita.

Desde o início do projeto, notamos que os professores(as) se surpreendiam ao serem convidados a falar sobre suas histórias e, por outro lado, gostavam de contá-las. Como mostramos interesse em saber o que os levou a serem professores, o que costumavam ler e escrever, eles rememoravam fatos passados, redescobrindo a si próprios. Na verdade, eles se surpreendiam ao se ouvirem. Aos poucos, percebemos o caráter formador das entrevistas: no período exploratório, notamos que a vida dos professores e sua prática pedagógica eram tratadas de forma separada: relatando as experiências vividas, seu modo de falar era diferente de quando tratavam da prática pedagógica. Isso configurou um dos desafios enfrentados, motivou o aprofundamento teórico e a análise crítica da própria entrevista, gerando um dos maiores aprendizados da pesquisa. Mas, se no início sabíamos que narrar e rememorar constituía importante movimento de ressignificação para o entrevistado, ao final, aprendemos que a entrevista se mostrava importante também para o entrevistador. ${ }^{15}$

Esse processo tem gerado reflexões sobre a prática pedagógica, sobre leitura e escrita de professores e sobre a relação entre pesquisa e políticas públicas. Temos questionado a prática comum em muitas secretarias de educação e universidades, que apaga suas próprias histórias e as de seus professores. Sabemos que propostas que negam a prática e a história dos professores geram reações de descrédito e aversão, da mesma maneira que teorias e alternativas práticas se desgastam porque sua implantação contradiz seu conteúdo: fala-se muito sobre linguagem, mas não se constrói um espaço de produção de linguagem. Além disso, políticas de formação efetiva de professores precisam garantir benefícios em que a formação se alia a aumento de salário, avanço na escolaridade e progressão na carreira. Formação é direito: direito de todos à educação; direito do professor e não favor de uma secretaria.

Pode o professor tornar seus alunos cidadãos se seus próprios direitos de cidadania não têm sido respeitados? E pode um professor que não gosta de ler ou escrever tornar seus alunos leitores e escritores? Mais do que formar o hábito de ler, trata-se de junto com ele criar, nas escolas e fora delas, práticas reais de leitura e escrita de crianças e de adultos, o que exige políticas de formação de professores concebidas e implementadas como parte de uma efetiva política cultural — que priorize a disseminação de bibliotecas e salas de leitura - e também uma política científica urgente.

No contexto dessas idéias, é que o papel da memória, das histórias de vida e autobiografias se torna essencial como alternativa às políticas de formação que passam uma borracha nas práticas construídas ao longo da história do país e das inúmeras histórias de professoras(es), escolas e projetos. A educação é aqui reconcebida e sua estreita ligação com a memória social vem à tona: educação passa a ser revista como parte da história, atribuindo papel

15. Cada entrevista foi realizada por uma dupla de pesquisadores — um graduando e um pós-graduando para garantir a triangulação, enfrentar a subjetividade e favorecer a formação de pesquisadores. 
central ao resgate da memória. Uma formação nessa linha subverte o apagamento da memória. Em geral, cada reforma educacional toma seu momento de implantação como início de tudo, atribuindo ao que veio antes a idéia de tradicional, de conservador, de atraso que precisa ser superado, prática que coloca a educação em ponto morto, que só seria alavancada por propostas pedagógicas inéditas ou mirabolantes.

As experiências que ouvimos e analisamos de professores(as) que atuaram nos anos 20/30/40 e 50/60, mostram que eles valorizam suas memórias. Ouvi-las, como à Xerazade, ensinou à equipe muito sobre leitura/escrita, sobre educação e sobre ser professor. Graças à narrativa - à experiência concreta que as constituiu e que, tornando-se experiência coletiva, constituiu naquele tempo seus alunos e constitui, hoje, suas entrevistadas - eles e elas puderam(podem) valorizar as histórias do outro e suas próprias histórias. O significado de ser professor se mostra claro: os professores e as professoras continuam contando e criando histórias.

Por outro lado, no que se refere à escrita, várias são as situações relatadas nas histórias dos entrevistados. Para que as pessoas escreviam e para que escrevem? E as professoras e professores de então e as/os de agora? Escrever serve para quê? Para se comunicar, expressar os sentimentos, contar fatos, armazenar informações, arquivar dados, registrar a história, denunciar, criticar, transgredir? Escreve-se para sobreviver? É útil ou inútil? Quer dizer, pode servir ou é inútil, pois não servindo nunca, é servil? Refletindo sobre a escrita, a partir desses anos de experiência na pesquisa, instituímos a prática de escrever atas e com vigor retomamos a discussão teórica sobre a escrita e a própria vontade de escrever. Por que e em que as experiências de escrever vividas pela equipe se diferenciam das práticas escolares? Como contribuem para pensar a formação? Fizemos desse tema questão de pesquisa para pensar a tensão entre, de um lado, o que significa para nós a escrita e, de outro, o que significa escrever para os professores entrevistados. Essa tensão move a pesquisa e nos mobiliza para sugerir estratégias de formação.

Talvez a importância da prática das atas, vivida na pesquisa, esteja no fato de elas terem, além dos aspectos analisados, restituído às professoras a possibilidade de aprender com a escrita e com a leitura (lembro que elas são escritas para serem lidas em conjunto). Cada uma reescreve a reunião anterior do grupo e, fazendo-o, nela se reinscreve. Aqui reside, fundamentalmente, sua dimensão formadora.

No passado, as pessoas aprendiam com a história vivida, contada, compartilhada, coletivizada. Hoje, com a desvalorização da experiência e do espaço da narrativa, trata-se somente de "aprender história"? Com essa perspectiva disciplinar, a história deixa de ser percebida como algo vivido e feito pelos homens e passa a ser matéria ensinada e aprendida. O mesmo parece acontecer com a leitura e a escrita: cada vez se enfatiza mais a necessidade de aprender a ler e a escrever e não a importância de aprender com a linguagem, com a leitura, com a escrita, compreendidas como experiências, como práticas sociais e culturais, mais do que como práticas escolares. A escola tem a obrigação de assegurar a todos o acesso 
ao conhecimento e, nesse sentido, garantir condições para práticas reais de leitura e escrita é seu dever. Por outro lado, entendemos que a formação é direito e a concretização de práticas de leitura/escrita precisa ser parte da formação de professores. Nesse processo, aprender com a experiência, rever a própria trajetória com a leitura e a escrita, reler aquilo que foi escrito em cada um de nós — e não só aquilo que aprendemos a escrever e a ler — podem se constituir em ações formadoras da maior importância.

Enfim, entendemos que "articular historicamente o passado não significa conhecê-lo como ele de fato foi", mas "apropriar-se de uma reminiscência, tal como ela relampeja no momento de perigo" (Benjamin, 1987a. p.224). Com esse espírito estamos, desde agosto de 1997, com o projeto Cultura, Modernidade e Linguagem: o que Lêem e Escrevem Futuros Professores e seus Mestres, que se propõe, de um lado, a pesquisar três escolas de formação (três escolas de $2^{\circ}$ grau — uma pública, uma particular de caráter confessional e uma cooperativa) e, de outro, a aprofundar o estudo da fotografia como desvio metodológico, sistematizando o acervo de fotos que revelam situações de leitura e escrita no cotidiano do Rio de Janeiro e de fotos trazidas como parte da memória.

Conhecer a formação cultural e as experiências de professores, inclusive na formação, é tarefa importante, considerando a situação salarial e funcional do magistério, em especial o problema da evasão: em 1995/1996, no Município do Rio de Janeiro, segundo o Sindicato Estadual de Profissionais da Educação, uma média de oito professores por dia útil deixou a rede. Em março/abril 1996, a média foi de seis professores. ${ }^{16}$

Orienta-nos, também neste momento, a concepção de que é necessário pensar a formação menos como treinamento linear e mais como história que se transforma, mais como formação cultural, se pretendemos que professores e professoras sejam sujeitos da história e sujeitos na história. Assim, ter um olhar agudo voltado ao passado, dirigindo-nos ao futuro, pode nos ajudar a repensar a situação grave vivida no presente e é este presente que precisamos encarar, embora mudá-lo pareça hoje tão difícil. Repensar o passado, ressignificálo, pensar e ressignificar o futuro, são ações que supõem indagar o presente, no presente, superando mitos e ilusões, colocando em questão soluções que têm se apresentado como imediatas e rápidas. Temos aprendido, nesse processo, que, como diz o poeta Brecht:

As novas épocas não começam de repente.

Meu avô já vivia num tempo novo,

meu neto com certeza ainda vai viver no antigo.

A carne nova é comida com os velhos garfos.

(apud Konder, 1996. p.70)

16. De acordo com a Secretaria Municipal de Educação do Rio de Janeiro, em 1996 o vencimento base do professor I (as quatro primeiras séries do $1^{\circ}$ grau) era $R \$ 133,00$; somado à $R \$ 242,00$ de gratificação de regência (perdida na aposentadoria) e $\mathrm{R} \$ 25,00$ de auxílio-transporte, totalizando salário de $\mathrm{R} \$ 400,00$. 


\section{PROFESSORES ENTREVISTADOS}

Adélia - 88 anos. Iniciou sua carreira no magistério em 1921 e aposentou-se em 1946.

Clara - 58 anos. Iniciou sua carreira em 1957. Atuou em sala de aula com turmas de I o grau ( l o segmento) e como supervisora. Graduada em pedagogia, continuava atuando em atendimento psicopedagógico.

Ciro - 76 anos. Iniciou sua carreira em 1931. Formou-se em pedagogia pela Universidade Estadual do Rio de Janeiro — UERJ — aos 65 anos. Continuava atuando no magistério em 1995.

Elizabeth - 7I anos. Iniciou sua carreira em 1940 e aposentou-se em 1968.

Estela - 64 anos. Iniciou sua carreira em 1950, como professora do $1^{\circ}$ grau ( ${ }^{\circ}$ segmento) da rede estadual no Rio de Janeiro. Aposentou-se em 1985. Foi diretora de escola.

Lara - 95 anos. Iniciou sua carreira em 1918, em escola particular. Em 1922, começou a atuar no morro Dona Marta, dedicou toda a sua vida em creches e atividades para a população. Fez serviço social.

Lena - 73 anos. Iniciou sua carreira como professora em 1942 e continuava atuando.

Luzia - aposentada da rede estadual do Rio de Janeiro. Graduada em pedagogia, continuou trabalhando na formação de professores em uma escola particular.

Marília - 62 anos. Iniciou sua carreira no magistério em 1954. Foi supervisora pedagógica. Graduada em pedagogia. Aposentou-se.

Rosa - 80 anos. Iniciou em 194I na escola pública e em 45 em escola particular. Fundou uma escola em Petrópolis. De 1951 a 1964 trabalhou no Instituto Brasileiro de Geografia e Estatística — IBGE —, no Departamento de Censo Agrícola.

Tereza - iniciou sua carreira no magistério em 1948 e aposentou-se em 1983. Atuou em sala de aula e na Secretaria de Educação. Atualmente é professora universitária.

Valda - professora da rede estadual e particular, no Rio de Janeiro. Foi professora do $1{ }^{\circ}$ grau $\left({ }^{\circ}\right.$ seg). Trabalha ainda em cursos de formação tanto da rede pública quanto particular. Mestre em educação.

Vilma - 75 anos. Atuou no magistério de 1940 a 1965. Aposentou-se da rede pública do Rio de Janeiro. Trabalhou também como bibliotecária.

\section{REFERÊNCIAS BIBLIOGRÁFICAS}

ALMEIDA, J. S. de Mulheres na escola: algumas reflexões sobre o magistério feminino. In: Cadernos de Pesquisa, São Paulo, n.96, p.7I-78, fev. 1996. 
ALMEIDA, M. J. de Imagens e sons. São Paulo: Cortez, 1994.

ABDALLA, C. Partilhando saber e prazer: um estudo etnográfico sobre uma comunidade de leitoras. Rio de Janeiro, 1995. Dissert. (mestr.) PUC-Rio.

ARIÈS, P. Por uma história da vida privada. In: ARIÈS, P., CHARTIER, R. (org.) História da vida privada: da Renascença ao século das luzes. São Paulo: Cia das Letras, v.3, p.7-19, 1991.

ARIĖS, P., CHARTIER, R. (org). História da vida privada: da Renascença ao século das luzes. São Paulo: Companhia das Letras, v.3, p. 37|-405, I99|

AUMONT, J. A Imagem. São Paulo: Papirus, 1995.

BAKHTIN, M. Estética da criação verbal. São Paulo: Martins Fontes, 1992.

Marxismo e filosofia da linguagem. São Paulo: HUCITEC, 1992.

BAZIN, A. Ontologia da imagem fotográfica. In: XAVIER, I. (org.). A Experiência do cinema. Rio de Janeiro: Graal, 1991.

BEN-PERETZ, M. Episódios do passado evocados por professores aposentados. In: NÓVOA, A. Vida de professores. Portugal: Porto, 1992.

BENJAMIN, W. Magia e técnica, arte e política. São Paulo: Brasiliense, 1987a. (Obras EscoIhidas, I).

. Rua de mão única. São Paulo: Brasiliense, 1987b. (Obras Escolhidas, 2).

. Origem do drama barroco alemão. São Paulo: Brasiliense, 1984.

BOSI, E. Memória e sociedade. São Paulo: Brasiliense, 1993.

BOTERO, J., MORRISON, K. (org). Cultura, pensamento e escrita. São Paulo: Ática, 1995. p. $101-39$.

BRANDÃO, S. et al. Narradores do cotidiano-vida, trabalho e memória de antigos professores. In: KRAMER, S. et al., Cultura, modernidade e linguagem: leitura escrita de professores em suas histórias de vida e formação. Rio de Janeiro: PUC, 1997.

BUTT, R. et al. Collaborative autobiography and the teacher's voice. In: GOODSON, I. F. Studying teachers' lives. London: Routledge, 1992.

CAMPOS, M. C. S. S. Formação do magistério em São Paulo: do Império a 1930. In: Cadernos de Pesquisa, São Paulo, n.72, p.5-16, fev. 1990.

CAVACO, M. H. Ofício de professor: o tempo e as mudanças. In: NÓVOA, A. (org). Profissão: Professor. Portugal: Porto, 1992. . A Cultura no plural. Campinas: Papirus, 1995 
. A Escrita da história. Rio de Janeiro: Forense Universitária, 1992.

CERTEAU, M. A Invenção do cotidiano: artes de fazer. Petrópolis: Vozes, 1994.

CHARTIER, A. M. La Formacion des enseignats en France et la creacion des institus universitaires de formation des maitres,. São Paulo: IUFM, 1996. mimeo.

. Lectures personelles et lectures professionnelles dans les trajectoires de formation. IUFM de Versailles, 1995. mimeo.

. Leitura escolar: entre pedagogia e sociologia. Revista Brasileira de Educação, São Paulo: ANPED, p. 17-52, set./dez. 1995.

CHARTIER, R. A História cultural: entre práticas e representações. Lisboa: Difusão Editorial, 1990.

. As Práticas da escrita. In: ARIÈS, P., DUBY, G. História da vida privada: da Renascença ao século das luzes. São Paulo: Cia. das Letras, |99| v. v.3, p. | |3-6|.

. (org). As Práticas da leitura. Rio de Janeiro: Estação Liberdade, 1996.

DAUSTER, T. A Formação do leitor. Rio de Janeiro, 1996. mimeo. [Trabalho apresentado na Jornada de Alfabetização]

DEMARTINI, Z. de B. F. et al. Magistério primário: profissão feminina, carreira masculina. In: Cadernos de Pesquisa, n.86. p. 5-14, ago. 1993.

DUBOIS, P. O Ato fotográfico. Campinas: Papirus, 1994.

FERRAROTTI, F. Histoire et histoires de vie. Paris: Librairie des Meridiens, 1982.

FRANGELLA, R. et al. Ser professora, instituir-se professora: a trajetória no Instituto de Educação. In: KRAMER, S. et al. Cultura, modernidade e linguagem. PUC, 1997. (Relatório de pesquisa).

FREIRE, P. Cartas a Cristina. Rio de Janeiro: Paz e Terra, 1994.

FREIRE, A. M. A.. Analfabetismo no Brasil. São Paulo: Ed. do Brasil, 1989.

GAGNEBIN, J. M. História e narrativa em Walter Benjamin. São Paulo: Perspectiva, 1994.

GERALDI, J. W. Portos de passagem. São Paulo: Martins Fontes, 1993.

GNERRE, M. Linguagem, escrita e poder. São Paulo: Martins Fontes, 1985.

GOODSON, I. F. Studying teacher's lives. London: Routledge, 1992.

GOULEMONT, J. M. As Práticas literárias ou a publicidade do privado. In: ARIÈS, P., CHARTIER, R. (org) História da vida privada: da Renascença ao século das luzes. São Paulo: Cia. das Letras, 1991. v.3, p. 37|-405.

HERRENSCHMIDT, C. O. O Todo, o enigma e a ilusão - uma interpretação da história da 
escrita. In: BOTERO, J., MORRISON, K. (org), Cultura, pensamento e escrita. São Paulo: Ática, 1995. p. I01-39.

HOLANDA, A. B. de. Dicionário da Língua Portuguesa. Rio de Janeiro: Nova Fronteira, 1986. . Mini dicionário de Língua Portuguesa. Rio de Janeiro: Nova Fronteira, 1977.

HORKHEIMER, M., ADORNO, T. Dialética do esclarecimento. Rio de Janeiro: Zahar, 1985.

HUBERMAN, M.. O ciclo vital de vida dos professores. In: NÓVOA, A. (org) Vida de Professores. Portugal: Porto, 1992.

JAPIASSU, H. Nascimento e morte das ciências humanas. Rio de Janeiro: Francisco Alves, 1982.

JACOBY, R. Os Últimos intelectuais. São Paulo: Trajetória Cultural; EDUSP, 1987.

KONDER, L. A Poesia de Brecht e a história. Rio de Janeiro: Zahar, 1996.

. Walter Benjamin: o marxismo da melancolia. Rio de Janeiro: Campus, 1988.

KRAMER, S. Alfabetização, leitura e escrita: formação de professores em curso. Rio de Janeiro: Papéis e Cópias e Escola de Professores, 1995.

. A Formação do professor como leitor e construtor de conhecimento. In: MOREIRA, A. F. Conhecimento educacionale formação do professor. Campinas: Papirus, 1994.

. Leitura e escrita de professores: da prática de pesquisa à prática de formação. PUC-Rio, 1997, [texto enviado para a RBE/ANPED] (no prelo).

. Pão e Ouro: burocratizamos a nossa escrita? In: BIANCHETTI, L. Trama e texto: leitura crítica, escrita criativa. São Paulo: Plexus, 1996. p. 169-75.

. Por entre as pedras: arma e sonho na escola. São Paulo: Ática, 1993.

KRAMER, S., LEITE, M. I. (org) Infância: fios e desafios da pesquisa. Campinas: Papirus, 1996.

KRAMER, S., SOUZA, S. J. (org) Histórias de professores: leitura, escrita e pesquisa em educação. São Paulo: Ática, 1996.

KRAMER, S. et al. Cultura, modernidade e linguagem: leitura e escrita de professores em suas histórias de vida e formação. PUC/Rio, 1996. (Relatório Parcial I e II.)

. Cultura, modernidade e linguagem: leitura e escrita de professores em suas histórias de vida e formação. PUC/Rio, 1997. (Relatório Parcial I e II.)

. Cultura, modernidade e linguagem: o que narram, lêem e escrevem os professores. Rio de Janeiro, 1993. (mimeo) (Projeto de Pesquisa.)

. Cultura, modernidade e linguagem: o que narram, lêem e escrevem os professores. Rio de Janeiro, 1994. (Relatórios Parciais I e II.) 
. Cultura, modernidade e linguagem: o que narram, lêem e escrevem os professores. Rio de Janeiro, 1995. (Relatório final da pesquisa.)

LEITE, M. I. et al. Retratos da história de professores. a fotografia como desvio metodológico. 1997. mimeo

LEITE, M. M. A Imagem através de palavras. In: LEITE, M. M. Retratos de familia. São Paulo: EDUSP, 1993.

LELIS, I. A. O. M. A Polissemia do magistério: entre mitos e histórias. Rio de Janeiro, 1996. Tese (dout.). PUC-Rio, Departamento de Educação.

LIMA, A. B. L., FRANGELLA, R. C. P. Foto-grafias: (re)tratos da história de uma professora. In: KRAMER, S. et al. 1997.

LISPECTOR, C. A Paixão segundo G.H. Rio de Janeiro: Nova Fronteira, 1986.

LOPES, A. E. R. C. Foto-grafando: sobre arte-educação e educação especial. 1996. Dissert. (mestr.) UERJ, Fac. de Educação.

MAGNI, C. T. O Uso da fotografia na pesquisa sobre habitantes de rua. Horizontes Antropológicos. Porto Alegre: Antropologia Visual, n.2, 1995.

MANACORDA, M. A. A História da educação: da antiguidade aos nossos dias. 3.ed. São Paulo: Cortez, 1992.

MENESES, A. B. de. Scherazade ou do poder da palavra. In: MENESES, A.B. Do poder da palavra: ensaios de literatura e psicanálise. São Paulo: Duas Cidades, 1995. p.39-56.

MENEZES, V. C. De geração em geração... histórias de vida: memória, leitura e escrita. [Trabalho apresentado na $19^{\text {a }}$ Reunião Anual da ANPED, Caxambu, set., 1996].

MIRANDA, W. M. Auto(bio)grafar: a ilusão autobiográfica. In: MIRANDA, W.M. Corpos escritos, São Paulo: EDUSP; Belo Horizonte: UFMG, 1992. p. 25-58.

MISSAC, P. Walter Benjamin's Passages. Cambridge, Mass: MIT Press, 1995.

MOITA, M. C. Percursos de formação e trans-formação. In: NÓVOA, A. (org) Vida de professores. Portugal: Porto, 1992.

MORAES, A. A. As Leituras de alunas de magistério: obrigação, vontade, possibilidade e escolha. São Paulo, 1994. Dissert. (mestr.) PUC-SP.

NEIVA JR., E. A Imagem. São Paulo: Ática, 1986.

NOVAES, M. H. Psicologia da terceira idade: conquistas possíveis e rupturas necessárias. Rio de Janeiro: Paulo de Frontin, 1995.

NÓVOA, A. (coord). Os Professores e a sua formação. Lisboa: Pub. Dom Quixote, 1992. 
. Profissão professor. 2.ed. Porto: Porto, 1995.

. (org.) Vidas de professores. Portugal: Porto, 1992.

NÓVOA, A., POPKEWITZ, T. S. (org). Reformas educativas e formação de professores. Lisboa: EDUCA, 1992.

NUNES, M. F. R. Os Interpretativos do mundo: histórias de vida de professores alfabetizadores. Rio de Janeiro, 1995. Dissert. (mestr.) UERJ.

OSWALD, M. L. B. Aprender com a literatura: uma leitura benjaminiana de Lima Barreto. Rio de Janeiro, 1997. Tese (dout.) Educação, PUC.

PENIDO, S. Walter Benjamin: a história como construção e alegoria. Cadernos do Dep. de Filosofia. Rio de Janeiro, PUC/RJ, n. I, p.61-70, jun. 1989.

PIMENTA, S. G. Revendo o ensino de $2^{\circ}$ grau: propondo a formação de professores. 2. ed. rev. São Paulo: Cortez, 1992.

ROMANELLI, O. História da Educação no Brasil. Petrópolis: Vozes, 1978.

SANTOS, R. Entre o sagrado e o profano: o lugar social do professor da cidade do Rio de Janeiro. Rio de Janeiro, 1994. Dissert. (mestr.) UFRJ.

SARTRE, J. P. Que é a literatura? São Paulo: Ática, 1989.

SONTAG, S. Sob o signo de Saturno. Porto Alegre: L \& PM Editores, 1986.

SOUSA, C. P. et al. Memória e autobiografia:formação de mulheres e formação de professoras. Revista Brasileira de Educação, n.2, p.6I-76, 1996.

STEIN, M. E. História e ideologia. Porto Alegre: Movimento, 1981.

VYGOTSKY, L. S. A formação social da mente. São Paulo: Martins Fontes, 1984. . (1987 a). Pensamento e Linguagem. São Paulo: Martins Fontes, 1987a.

WISMANN, H. (ed.) Walter Benjamin et Paris. Paris: Les Editions du Cerf, 1986. 